DOI: $10.22616 /$ REEP.2020.009

\title{
Self-Evaluation of Programmers' Competitiveness in an IT Company as Learning Organisation
}

\author{
Edgars Katans ${ }^{1}$ Mg.paed.; Irena Katane ${ }^{2}$ Dr.paed.; Regina Baltusite ${ }^{3}$ Dr.paed. \\ IT Company “Autentica”, Latvia ${ }^{1}$; Latvia University of Life Sciences and Technologies, Latvia ${ }^{2 ; 3}$ \\ edgars.katans@autentica.lv; ; irena.katane@inbox.lv²; regina.baltusite@1lu.lv
}

\begin{abstract}
Professional development of programmers is a lifelong process that takes place both within and outside the IT company. There are several types of knowledge management in the IT company as a learning organisation. Within the framework of knowledge management, the professional development of the company's specialists, career guidance, and learning-facilitation take place at IT company environment. The result of successful professional development is the programmer's competitiveness. The aim of the research: to conduct a pedagogical experiment to promote the development of adequate self-evaluation of programmers' competitiveness using the developed methodology in learning/knowledge IT organisations. A methodology for evaluating programmers' competitiveness was developed. Within the framework of an empirical research, programmers assessed their competitiveness in two ways: 1) using self-assessing methodology with 28 indicators of the programmers' competitiveness as a pedagogical tool of influence of self-evaluation performed by the research participants; 2) both before and after approbation of this developed self-assessing methodology using a modified projective linear scale to obtain an express-assessment of programmers' competitiveness in a holistic view. A survey was organized among programmers working in various IT companies: 1) Latvian enterprises without representations abroad, 2) Latvian enterprises with foreign representations; 3) foreign companies with representations in Latvia. This survey was by nature a kind of pedagogical experiment. The results of the research testify that developed competitiveness assessment methodology influenced programmers' selfevaluation during pedagogical experiment. There are three types of trends, namely, after approbation of the competitiveness self-assessing methodology the programmers self-evaluations: 1) remained unchanged; 2) increased, the respondents, thanks to the methodology, identified their strengths, which had not been properly evaluated so far; 3 ) decreased, because respondents, thanks to the methodology, found out about their weaknesses, which until now have not been identified.
\end{abstract}

Keywords: IT company, knowledge management, learning organisation, methodology of selfevaluating, pedagogical experiment, programmers' competitiveness.

\section{Introduction}

Mutually complementing transdisciplinary paradigms of information and knowledge society became a part of social sciences. In order the society could ensure its sustainable development, it must be able to make constant changes and it must learn to adapt to the changes happening around. This is possible if the society in general, various organisations within the society and each individual person of the society is constantly learning, accumulating and creating new knowledge and sharing it. In its turn, an important aspect of the process of knowledge acquisition and development is the access to the required information, its critical selection, fast exchange and storing of important information. It is all ensured by the introduction of modern information and communications technologies not only in science and education, but also in the professional activity and everyday life of each individual person. In the knowledge society, everyone is learning and teaching, acquiring a self-directed learning competency and also a pedagogical competency in teaching others in order to acquire newer experience and to share it at an individual level, at the level of a social group, enterprise (as organisation) and the whole society. Consequently, the role of lifelong education becomes more topical in the information and knowledge society, so to be able to sustain constantly changing conditions (Cerroni, 2018; Katane, Katans, 2018; Katane, Katans, Vāvere, 2012). The information and knowledge society as the system of correlation in the exchange of information and knowledge should be more considered as a continuing process and a result of this correlation and development.

To ensure its competitiveness and sustainability in the constantly changing information and knowledge society, many IT companies become learning/knowledge organisations. The activity of learning/knowledge organisations has a number of specific characters or indicating elements that help to distinguish them from 
common organisations. Researches of learning/knowledge enterprises, including IT companies, are the topical subjects of the 21 ${ }^{\text {st }}$ century (Alipour, Karimi, 2018; Argote, 2013; Argote, Hora, 2017; Suleimankadieva, Pilipenko, Sági, 2019).

To be able to sustain competition continuously, an enterprise must not only focus on the quality of its activity, provided services, products and their marketability, but also it must promote continuous professional development of its specialists, ensuring professional training and re-training within the enterprise, which has a strong effect on the corporate culture of the enterprise. For this purpose, the enterprise must ensure all possible types of knowledge management. Nowadays knowledge is the prerequisite and the basis for high quality and high-performance business of any company. Knowledge management is a complex of certain methods of HR and education management, as well as a complex of technological methods that help to improve the quality of specialists' work in a company. The system of knowledge management in a company as learning/knowledge organisation is oriented at the exchange and increasing of knowledge resources, which ensures intellectual capital of the company. Considering that the notion of knowledge management arose in close connection with the development of information and communications technologies, many scientific researches are related to knowledge management in IT companies. Knowledge management in IT companies not only includes sharing of current knowledge or ensuring of obtaining missing knowledge, it also involves an integrated approach used for identifying, evaluating, retrieving and sharing all of an enterprise's information assets.These assets can include databases, documents, procedures, various information and communications technologies, electronic environment of a company etc. Moreover, the knowledge management is closely connected to the change management within companies (Giannetto, Wheeler, 2000; Lipowsky, 2017; Little, 2014; Pinto et al., 2017; Socking, 2018).

At a learning/knowledge organisation, one of the basic functions that ensure its development is the diagnostics and investigation of problems existing in the company: analysis and evaluation, which makes it possible to eliminate or to solve such problems. Within the knowledge management context, the same can be done in relation to the investigation of the expertise and the professional activity of the existing specialists, in other words, companies must investigate the needs of professional development, career growth and education of their specialists in order to be able to give them necessary support. One of the methods for such investigation is reflection-based self-evaluation methodologies (Katane et al., 2015).

The process of constructing, exchanging and learning as obtaining of new knowledge is not only a competitive advantage of a company but also a guarantee of professional development and further progress for a company's specialists, following new tendencies in a respective field, acquiring and implementing the newest (innovative) trends in the professional activity of its specialists. The increase of competitiveness of employees results in the increase of competitiveness of the company, and vice versa. Therefore, one of the tasks of the knowledge management in a company is to elaborate and implement the methodology of selfevaluating of the professional development of specialists, including the self-evaluating of its result: programmers' competitiveness. The indicators of the self-evaluating methodology in the reflection process allow the specialists to evaluate their own competitivenes, including various competences, various qualities (strengths and weaknesses) and professional activity (advantages and disadvantages). The knowledge about themselves as professionals becomes a basis for professional self-development, career self-management, self-directed continuous learning of specialists, as well as acquiring and sharing new experience. This is an important precondition for the learning company to be able to ensure the knowledge management for its development, competitiveness and sustainability (Katans, 2019). It is important to point out that specialist's competitiveness is a complex totality of a person's qualities that ensure the viability, development, professional self-realization, his/her competitive actions in the changeable environment, including specialist's marketability and employability in the modern labor market (Katane, 2010).

During the last years, several studies both in Latvia and abroad (Belenov et al., 2017; Emelyanova, Voronina, 2018; Evplova, 2019; Iriste, 2018) show that research on the competitiveness of specialists in various industries is topical in the modern social sciences, including educational sciences.

The aim of the research: to conduct a pedagogical experiment to promote the development of adequate self-evaluation of programmers' competitiveness using the developed methodology in learning/knowledge IT organisations. 


\section{Methodology}

There were three stages of the research: 1) preparation stage; 2) pedagogical experiment performed by approbation of the developed methodology for self-assessment of programmers' competitiveness; 3 ) summarizing and processing of data, analysis and evaluation of the results obtained.

Methods of research: 1) data obtaining methods: survey (questionnaires); 2) data processing methods: primary mathematical processing of data to produce descriptive statistics; secondary mathematical processing of data to produce conclusive statistics using Wilcoxon Test (SPSS software 21.0, 2019).

During the preparation stage, the methodology for the assessment of programmers' competitiveness was elaborated with 28 assessment indicators. Previous researches in the respective field were used as a theoretical basis of the elaborated system of indicators for the assessment of programmers' competitiveness, including their competences.

The results of previous theoretical studies show that there are three methodological approaches to the scientific substantiation of personality/specialist competitiveness in pedagogy (Iriste, 2018; Kalnina, Katane, 2010; Katane, 2010): 1) functional approach; 2) qualitative approach; 3) structural approach (Figure 1).

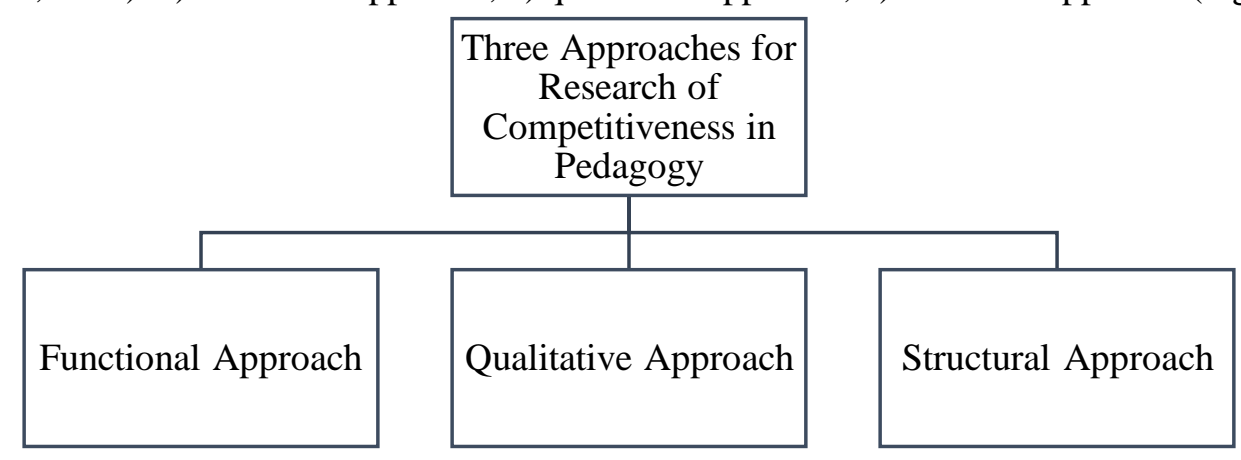

Figure 1. Methodological Approaches to Specialist's Competitiveness Research in Pedagogy (created by authors).

These approaches are evident in the research of engineers'/programmers' competitiveness as well (Katane, Baltusite, Katans, 2017).

Functional approach: competitiveness is substantiated by describing the manifestations of personality's competitiveness, as well as readiness for various actions, including interaction with the external environment. For example, the scientists L.V. Suyazova, D.A. Mustafina, I.V. Rebro, G.A. Rahmankulova (Suyazova et al., 2013) point out that a competitive engineer is: 1) a professional who can find the most appropriate solution for a problem; 2) a specialist who has various special abilities for professional activity in the changeable professional environment and in the society as social environment; 3) a personality who has qualities, including abilities, for self-development. In turn, A. Laaksonen (Laaksonen, 2018) and J. Sijin (Sijin, 2018) show the programmer's competitiveness including professional competence as manifestations of competitive professional activity during the programming process.

Qualitative approach: competitiveness is characterized as a totality of personality's several qualities, where these qualities serve as the indicators of competitiveness. For example, a number of various competences and personal qualities is pointed out, ensuring the competitive activity of an engineer and his competitiveness in general: motives and value orientations; the desire and ability to selfdevelopment, self-realization; civil qualities; high professional competence; leadership qualities; corporate competence; cultural humanitarian competence; socio-economic competence; creativity abilities; communicative competence; adaptability (Khairullina et al., 2015).

Structural approach: there is a structural model of competitiveness provided, emphasizing several components. For example, L. Mitina (Mitina, 2003) developed the model of the personality competitiveness structure with three components: personality direction, competence and flexibility. In turn, I. Katane (Katane, 2011) worked out and scientifically substantiated the model of specialist's competitiveness structure, where five components are present: the component of personality progression (including professional progression); the component of self-regulation (including volition, emotions and personality's 
flexibility); the component of self-conception (including self-evaluation and professional self-identity); the component of individual qualities (including purposefulness, intelligence, charisma, decision making, responsibility, sense of humor, creativity, ability to persuade, captivate, inspire; ability to dare and to take reasonable risks; ability to change and self-develop); the component of competence (including various professional competencies). The base of specialist's competitiveness is the accumulated expierience.

In the developed system of competitiveness self-assessment indicators, the authors of this article included those 28 indicators, which are most often found in the justification of competitiveness of personality/specialist/programmer given by different authors.

A pedagogical experiment was performed with the participation of 75 programmers from various Latvian IT companies, mostly located in Riga or nearby, and some of the participants specified that they are working for an IT company located in other cities of Latvia.

All the participants of the research represented IT companies of three types: 1) Latvian enterprises without representations abroad, 2) Latvian enterprises with foreign representations; 3) foreign companies with representations in Latvia. There were 7 women among 75 research participants. The youngest participant was 20 years old, but the age of the oldest participant was 50 years old. The participants had also a bit different overall work experience and the experience in programming as well: Min $=1$ year; Max $=25$ years.

Within the framework of the experimental research, programmers assessed their competitiveness in two ways: 1) using self-assessing methodology with 28 indicators as a pedagogical tool for self-evaluation influence performed by the research participants; 2) both before and after approbation of this developed self-assessing methodology using a modified projective linear scale to obtain an express-assessment of programmers' competitiveness in holistic view (Figure 2).

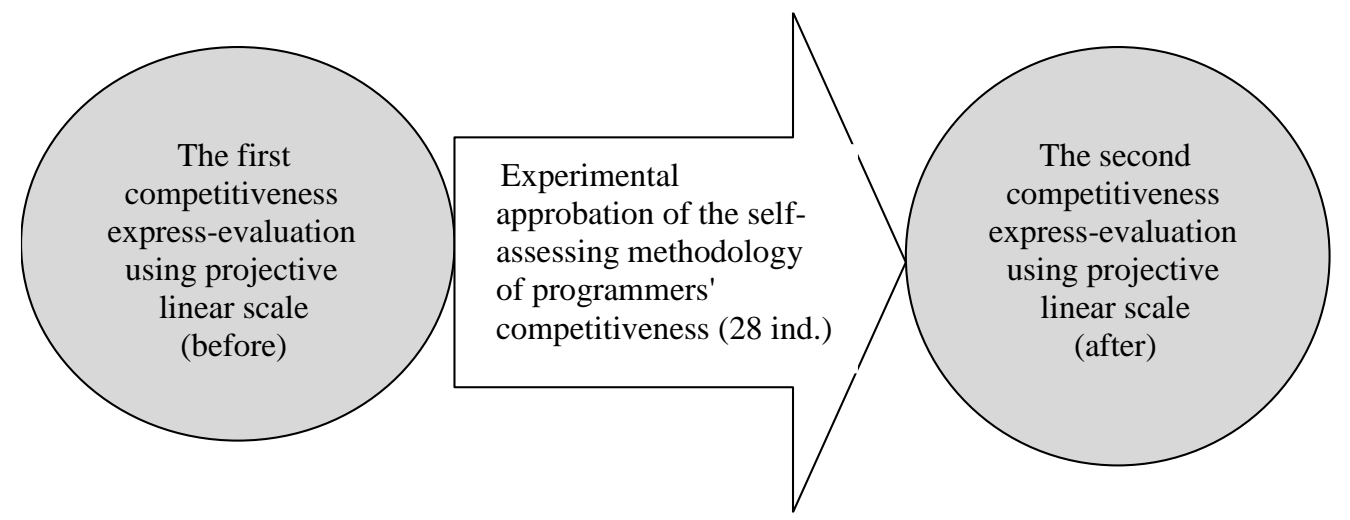

Figure 2. Design of pedagogical experiment (created by authors).

All the 75 participants performed an express-evaluation of their competitiveness at the beginning and at the end of the experiment, using a projective linear scale especially elaborated for this purpose by the research authors, which represents one of the types of modified projective tests. The theoretical aspects of the elaboration of the linear scale as a method of data acquisition were based on the projective method of Dembo-Rubinstein (Katane, Katans, Vìtols, 2019; Katans, 2019), which has been also used as a basis for modification and approbation of the authors' proprietary methodologies. The upper end of the modified projective linear scale specified: The highest level of competitiveness, which reflected the highest possible self-assessment of competitiveness, while the bottom end: the lowest level of competitiveness, which reflected the lowest possible self-assessment of competitiveness. The participants of the research had to mark the linear scale with a cross without thinking long, based more on intuition rather than on critical thinking. The linear scale allowed acquiring the assessment from 1 to 10.

\section{Results and Discussion}

\section{The results of the experimental approbation of the system of indicators for programmers' competitiveness evaluation}

On the first stage of summarizing and processing of data obtained during the research, it was important to answer the first research question: What are the self-evaluations of competitiveness by the participants in the experimental group in accordance with 28 indicators of the developed evaluation methodology? 
During the pedagogical experiment, the system of indicators for evaluation of programmers' competitiveness elaborated by the research authors was used as a pedagogical tool of influence of self-evaluation performed by the research participants. The system of indicators consisted of two relative subsections that were not highlighted in the questionnaire: 1) 11 indicators for evaluation of competitiveness of a programmer as a personality; 2) 17 indicators for evaluation of competitiveness of a programmer as a professional. The participants of the research had to assess, which of the attributes of competitiveness are and are not typical for them: 1 of 4 answers could be chosen in accordance with each indicator (yes; more likely yes than no; more likely no than yes; no). Processing the data, the dichotomous scoring scales were created, which included both positive answers ("yes" and "more likely yes than no") and both negative answers ("more likely no than yes" and "no"). Each indicator was ranked according to the positive responses' coefficient values.

Descriptive statistics of the answers provided by the research participants according to the 11 indicators of personality competitiveness are summarized in Table 1.

Table 1

Results of programmers' personality competitiveness self-assessment $(n=75)$

\begin{tabular}{|c|c|c|c|c|}
\hline \multirow[b]{2}{*}{$\mathbf{N}$} & \multirow[b]{2}{*}{ Indicators of Self-Assessment } & \multicolumn{2}{|c|}{$\begin{array}{l}\text { Positive self- } \\
\text { assessments }\end{array}$} & \multirow[b]{2}{*}{ Rank } \\
\hline & & n & $\begin{array}{c}\text { Coefficient } \\
\text { of specific } \\
\text { weight }\end{array}$ & \\
\hline 1. & $\begin{array}{l}\text { Ind.8. Ability to learn from their own and others' experience, including } \\
\text { form their own and others' achievements and mistakes. }\end{array}$ & 74 & 0,99 & 1 \\
\hline 2. & Ind.1. Clear future plans and aims of activity for the near and far future. & 70 & 0,93 & 2,5 \\
\hline 3. & $\begin{array}{l}\text { Ind.11. Psychological readiness for continuous learning during the whole life } \\
\text { in order to ensure personal development and lifelong education. }\end{array}$ & 70 & 0,93 & 2,5 \\
\hline 4. & Ind.7. Ability to plan and self-manage their time and activity. & 69 & 0,92 & 4 \\
\hline 5. & $\begin{array}{l}\text { Ind.9. The ability to dare and risk, including not being afraid of mistakes, } \\
\text { difficulties, changes: openness to new challenges. }\end{array}$ & 68 & 0,91 & 5 \\
\hline 6. & $\begin{array}{l}\text { Ind.23. Flexibility in thinking and acting, including the ability to change } \\
\text { plans if required by current situation or changing environment. }\end{array}$ & 66 & 0.88 & 6 \\
\hline 7. & $\begin{array}{l}\text { Ind.15. High-level self-competence, including the reflexive competence, } \\
\text { self-study, self-management, self-evaluation and self-development. }\end{array}$ & 65 & 0,87 & 7 \\
\hline 8. & $\begin{array}{l}\text { Ind.3. The ability to provide adequate evaluation of their knowledge, skills, } \\
\text { competencies, experience: strengths and weaknesses. }\end{array}$ & 62 & 0,83 & 8,5 \\
\hline 9. & $\begin{array}{l}\text { Ind.4. Knowledge of how to learn and develop in future, which is already } \\
\text { being done. }\end{array}$ & 62 & 0,83 & 8,5 \\
\hline 10. & $\begin{array}{l}\text { Ind.5. Pronounced will power, ability of self-mobilisation for activities, } \\
\text { including for those which are disliked or are performed with troubles. }\end{array}$ & 61 & 0,81 & 10 \\
\hline 11. & Ind.6. High working capacity. & 58 & 0,77 & 11 \\
\hline
\end{tabular}

The obtained results of programmers' personality competitiveness self-assessment testify that the highest value of positive responses (coefficients of specific weight) was obtained according to the following indicators (Table 1):

- Indicator 8: Coefficient of specific weight: 0,99; Rank: 1;

- Indicator 1: Coefficient of specific weight: 0,93; Rank: 2,5;

- Indicator 11: Coefficient of specific weight: 0,93; Rank: 2,5.

The lowest values of positive responses (coefficients of specific weight) were obtained according to the following indicators (Table 1):

- Indicator 5: Coefficient of specific weight: 0,81; Rank: 10;

- Indicator 6: Coefficient of specific weight: 0,77; Rank: 11.

The results of programmers' professional competitiveness self-assessment allow to conclude that the highest values of positive responses (coefficients of specific weight) were obtained according to the following three indicators (Table 2):

- Indicator 24: Coefficient of specific weight: 1,00; Rank: 1; 
- Indicator 17: Coefficient of specific weight: 0,99; Rank: 3;

- Indicator 21: Coefficient of specific weight: 0,99; Rank: 3;

- Indicator 25: Coefficient of specific weight: 0,99; Rank: 3.

Table 2

Results of programmers' professional competitiveness self-assessment $(n=75)$

\begin{tabular}{|c|c|c|c|c|}
\hline \multirow[b]{2}{*}{$\mathbf{N}$} & \multirow[b]{2}{*}{ Indicators of Self-Assessment } & \multicolumn{2}{|c|}{$\begin{array}{l}\text { Positive self- } \\
\text { assessments }\end{array}$} & \multirow[b]{2}{*}{ Rank } \\
\hline & & $\mathbf{n}$ & $\begin{array}{l}\text { Coefficient } \\
\text { of specific } \\
\text { weight }\end{array}$ & \\
\hline 1. & $\begin{array}{l}\text { Ind.24. Ability to solve complicated professional tasks independently, } \\
\text { competently and creatively. }\end{array}$ & 75 & 1,00 & 1 \\
\hline 2. & Ind.17. Ability to work in a programmers' team. & 74 & 0,99 & 3 \\
\hline 3. & $\begin{array}{l}\text { Ind.21. Responsible, timely (within the defined time limits) and high- } \\
\text { quality professional activity of a programmer. }\end{array}$ & 74 & 0,99 & 3 \\
\hline 4. & $\begin{array}{l}\text { Ind.25. Efficiency of the professional activity in performing both } \\
\text { urgent short-term tasks and large volume long-term projects. }\end{array}$ & 74 & 0,99 & 3 \\
\hline 5. & $\begin{array}{l}\text { Ind.10. Logically analytical, symbolically abstract, critical, systematic } \\
\text { and creative thinking. }\end{array}$ & 73 & 0,97 & 5,5 \\
\hline 6. & $\begin{array}{l}\text { Ind.20. Respecting of the activity policy, development strategy and } \\
\text { business interests of IT company he works for. }\end{array}$ & 73 & 0,97 & 5,5 \\
\hline 7. & $\begin{array}{l}\text { Ind.18. Pleasure and ability to work according to Agile methodologies, } \\
\text { incl. Scrum. }\end{array}$ & 69 & 0,92 & 7 \\
\hline 8. & Ind.12. High-level professional competence in IT field. & 65 & 0,87 & 8 \\
\hline 9. & Ind.26. Professional specialization in various fields. & 64 & 0,85 & 9 \\
\hline 10. & $\begin{array}{l}\text { Ind.2. Readiness and ability to arrange their career goals in line with } \\
\text { the goals of development and activity of IT company. }\end{array}$ & 63 & 0,84 & 10,5 \\
\hline 11. & Ind. 19. A sense of belonging to the IT company I work for. & 63 & 0,84 & 10,5 \\
\hline 12. & $\begin{array}{l}\text { Ind.16. Tracking and investigating of new trends in IT field related to } \\
\text { his professional activity. }\end{array}$ & 62 & 0,83 & 12 \\
\hline 13. & $\begin{array}{l}\text { Ind.28. If necessary, readiness to re-specialization in programming or even } \\
\text { in a completely different field of professional activity, creating successful } \\
\text { personal career and ensuring personal competitiveness in a job market. }\end{array}$ & 61 & 0,81 & 13 \\
\hline 14. & $\begin{array}{l}\text { Ind.22. Close and efficient cooperation with the client(s) of an IT } \\
\text { company he works for. }\end{array}$ & 58 & 0,77 & 14 \\
\hline 15. & Ind.27. Absence of professional burnout symptoms. & 50 & 0,67 & 15 \\
\hline 16. & Ind.14. High-level social competence, including communication. & 44 & 0,59 & 16 \\
\hline 17. & Ind.13. High-level economical and business competence. & 42 & 0,56 & 17 \\
\hline
\end{tabular}

The lowest values of positive responses (coefficients of specific weight) were obtained according to the following indicators (Table 2):

- Indicator 27: Coefficient of specific weight: 0,67; Rank: 15;

- Indicator 14: Coefficient of specific weight: 0,59; Rank: 16;

- Indicator 13: Coefficient of specific weight: 0,56; Rank: 17.

Analyzing and comparing the obtained results of descriptive statistics (Table 1; Table 2), it can be concluded that the competitiveness of a programmer as a professional is evaluated more critically than the competitiveness of a programmer as personality.

\section{The results of approbation of the methodology for evaluation of competitiveness of programmers as a pedagogical experiment}

During the following stage of mathematical data processing using SPSS software (21.0), we obtained descriptive statistics of the programmers' competitiveness express-assessments before and after the pedagogical experiment (Table 3), answered the second research question: Do programmers' self- 
evaluations differ before and after a pedagogical experiment using projective linear scale? The results show that there are differences between values of some indicators of descriptive statistics (Table 3 ).

Table 3

Descriptive statistics of competitiveness express-assessments by participants obtained at the beginning and end of the pedagogical experiment using projective linear scale $(n=75)$

\begin{tabular}{|c|c|c|}
\hline \multirow{2}{*}{ Values } & \multicolumn{2}{|c|}{ Results of the pedagogical experiment } \\
\cline { 2 - 3 } & Before & After \\
\hline Min & 3 & 4 \\
\hline Max & 9 & 9 \\
\hline A & 6 & 5 \\
\hline Me & 7 & 7 \\
\hline Mo & 8 & 7 \\
\hline$\sum$ & 530 & 504 \\
\hline
\end{tabular}

The results have been compared with the aim: to establish how significant the differences are? For a mathematical data processing for the obtaining conclusive statistics, the Wilcoxon Test has been used in a SPSS 21.0 software in order to define the difference between the two correlated samples obtained at the beginning and at the end of the experiment. The conclusive statistics results are demonstrated in Table 4.

Table 4

Results of Conclusive Statistics ( $n=75)$

\begin{tabular}{|c|c|c|}
\hline $\mathbf{N}$ & Wilcoxon Test & The obtained results of conclusive statistics \\
\hline \multirow[t]{2}{*}{1.} & \multicolumn{2}{|l|}{ Hypotheses for data processing } \\
\hline & $\begin{array}{r}\mathrm{H}_{0}: \mathrm{PCEA}_{1}=\mathrm{PCEA}_{2} \\
\mathrm{H}_{1}: \mathrm{PCEA}_{1} \neq \mathrm{PCEA}_{2}\end{array}$ & p-value $=0,000<\alpha=0,001$ \\
\hline \multirow[t]{4}{*}{2.} & Differences & \\
\hline & Positive differences: & 33 \\
\hline & Negative differences: & 7 \\
\hline & Ties: & 35 \\
\hline
\end{tabular}

PCEA $_{1}$ - The first programmers' competitiveness express-assessment in the beginning of the experiment.

PCEA $_{2}$ - The second programmers' competitiveness express-assessment in the end of the experiment.

The results of conclusive statistics allow for the following conclusions.

- There are three types of trends, namely, after approbation of the competitiveness self-assessing methodology the programmers self-evaluations: 1) remained unchanged; 2) increased, as the respondents, thanks to the methodology, identified their strengths, which had not been properly evaluated so far; 3 ) decreased, because respondents, thanks to the methodology, found out about their weaknesses, which have not been identified until now.

- The differences between programmers' expres-evaluations before and after the approbation of the developed competitive assessing methodology are statistically important.

\section{Conclusions}

1. One of the tasks of the knowledge management in an IT company is to elaborate and implement the methodology of self-evaluating of the professional development and competitiveness of programmers. This is an important precondition for the learning company to be able to ensure its development, competitiveness and sustainability.

2. During the experimental research changes were noticed in the self-assessments of experimental group participants' competitiveness. Self-assessments of competitiveness provided by the participants at the end of the experiment differed from the self-assessment of competitiveness at the beginning of the experiment, which is confirmed by the results of descriptive statistics. The results of conclusive statistics show that these changes were statistically important.

3. It is very important to know the indicators of programmers' competitiveness evaluation, as this knowledge affects the self-perception of programmers as a competitive personality and 
a competitive professional, changing the self-assessment of competitiveness, allowing for selfmanagement of personal development and self-realising in various ways, including the formal and non-formal education in the learning IT company and out of it.

4. Thanks to the approbation of the methodology for programmers' competitiveness evaluation consisting of 28 indicator system, the self-assessment of competitiveness of research participants at the end of the research: 1) increased, as the strengths that could be related to the attributes of competitiveness have not been fully understood; 2) decreased, as the assessment indicators have been evaluated based on many such aspects which have not been possibly considered before, therefore, more weak points have been taken into account; 3 ) did not change, as the assessment was relatively adequate at the beginning of the experiment (neither increased nor decreased).

5. The developed system of programmers' competitiveness indicators includes many such indicators that allow making self-assessment of various competences: self-competence, professional competence in programming, economic and business competence; social competence. The indicators of the selfevaluation methodology in the reflection process not only allow the programmers to evaluate their own various competences and professional activity, but also allow for assessing of various other qualities (strengths and weaknesses). The knowledge about themselves as professionals, including the advantages and disadvantages of their professional activity, becomes a basis for professional selfdevelopment, career self-management, self-directed continuous learning of specialists, as well as acquiring and exchanging new experience in the learning IT companies.

6. The participants acquired new experience of reflection during the experiment, which can serve as a basis for the adequate self-evaluation of competitiveness and for its development.

7. The experimentally approved methodology for self-evaluation of programmers' competitiveness is valid and can be used in further researches.

\section{Bibliography}

1. Alipour F., Karimi R. (2018). Creating and Developing Learning Organization Dimensions in Educational Settings; Role of Human Resource Development Practitioners. International Journal of Management, Accounting and Economics, 5(4), 197-213. Retrieved from http://www.ijmae.com/files/accepted/857_final.pdf

2. Argote L. (2013). Organizational Learning: Creating, Retaining and Transferring Knowledge. NewYork: Springer US. doi: 10.1007/978-1-4614-5251-5

3. Argote L., Hora M. (2017). Organizational Learning and Management of Technology. Production and Operations Management, 26(4), 579-590. doi: 10.1111/poms.12667

4. Belenov O.N., Zvezdinskaya A.V., Kolesnikova O.A., Maslova E.V. (2017). Konkurentosposobnost' kak faktor uspeshnosti molodogo specialista na rinke truda [Competitiveness as a factor of young specialists' success in labor market]. Voronezh: Izdatelskiy dom VGU. Retrieved from http://ccedcomplete.com/deliverables/wp5_articles_employability_in_the_labour_market_ru.pdf (in Russian)

5. Cerroni A. (2018). Steps Towards a Theory of the Knowledge-Society. Social Science Information, 57(2), 322-343. doi: 10.1177/0539018418767069

6. Emelyanova N.A., Voronina E.A. (2018). Competitiveness of a Specialist: Undergraduates' Expectations and Strategies. Psychological-Educational Studies, 10(4), 53-64. doi: 10.17759/psyedu.2018100406 (in Russian)

7. Evplova E.V. (2019). Social Charasteristics of Personal and Corporate Competitiveness of Future Specialsists: Results of Sociological Research. Educational and Science Journal, 21(2), 132-154. doi: 10.17853/1994-5639-2019-2-132-154 (in Russian)

8. Giannetto K., Wheeler A. (2000). Knowledge Management Toolkit. Swansea: Gower Published Co Limited.

9. Iriste S. (2018). Prospective Managers' of Hospitality Business Competitiveness Evaluation and Development promotion in the Dual Study Environment of Higher Education Institution. (Summary of Doctoral Thesis. Jelgava, LLU), 48-97. Retrieved from https://llufb.llu.lv/dissertationsummary/pedagogics/Sandra_Iriste_prom_darba_kopsavilkums2018_LLU_IMI.pdf

10. Kalniņa I., Katane I. (2010). Personality Competitiveness: Structure and Indications in Pedagogy. LLU Raksti, 24(319), 65-75. Retrieved from https://llufb.llu.lv/proceedings/n24/8/LLU_raksti_Nr24-65-75.pdf

11. Katane I. (2010). Competitiveness of Personality as a New Concept in Modern Education and Pedagogy Science. In L. Malinovska, V. Osadcuks (Eds.), The Proceedings of the $9^{\text {th }}$ Interational 
scientific Conference Engineering for Rural Development, 9. Jelgava: LLU, 327-334. Retrieved from http://www.tf.1lu.lv/conference/proceedings2010/Papers/62_Katane_Irena.pdf

12. Katane I. (2011). Methodological Bases for Evaluation of Specialist Competitiveness. In L. Malinovska, V. Osadcuks (Eds.), The Proceedings of the $10^{\text {th }}$ International Scientific Conference Engineering for Rural Development, 10. Jelgava: LLU, 524-529. Retrieved from http://www.tf.llu.lv/conference/proceedings2011/Papers/097_Katane.pdf

13. Katane I., Baltusite R., Katans E. (2017). Theoretical Background for Investigation and Promotion of Engineers Competitiveness in Education. In A. Aboltins (Ed.), The Proceedings of the International Scientific Conference Engineering for Rural Development, 16. Jelgava: LLU, 824-831. Retrieved from http://www.tf.llu.lv/conference/proceedings2017/Papers/N169.pdf

14. Katane I., Katans E. (2018). Environmental Contexts of Programmer's Professional Self-Development Through Learning: Ecological and Synergetic Approach. In A. Aboltins (Ed.), The Proceedings of the $17^{\text {th }}$ International Scientific Conference Engineering for Rural Development, 17. Jelgava: LLU, 1055 - 1064. doi: 10.22616/ERDev2018.17.N057

15. Katane I., Katans E., Vāvere G. (2012). Environment of Distance Learning for Humanization and Democratization of Education: the historical aspect. In V. Dislere (Ed.), The Proceedings of the International Scientific Conference Rural Environment. Education. Personality (REEP), 5. Jelgava: LLU, 35-42. Retrieved from https://lufb.llu.lv/conference/REEP/2012/REEP-2012-proceedings-E-ISSN-2255-808X.pdf

16. Katane I., Katans E., Vītols G. (2019). Programmētāju konkurētspējas pašnovērtēšanas metodika mūžizglītības un profesionālās pašattīstības kontekstā [Self-Evaluation Methodology of Programmers' Competitiveness in the Context of Lifelong Education and Professional Self-Development]. In the Proceedings of the International Scientific Conference Society. Intagration. Education, 5. Rezekne: RTA, 169-185. doi: 10.17770/sie2019vol5.3861 (in Latvian)

17. Katane I., Kristovska I., Vjatere G., Katans E. (2015). Evaluation, Support and Promotion of specialists' competitiveness development in Modern Enterprise as Learning Organization. Discourse and Communication for Sustainable Education, 6(1), 50 - 71. doi: 10.1515/dcse-2015-0004

18. Katans E. (2019). Programmētāja profesionālās attīstības veicināšana mācìties spējīgā IT uznēèumāa zināšanu pārvaldības skatījumā [Promoting the Professional Development of Programmers in a Learning IT Company from the Perspective of Knowledge Management]. Jelgava: LLU (in Latvian).

19. Khairullina E.R., Pochinova T.V., Khisamiyeva L.G., Sakhipova Z.M., Fedorova L.V., Ablyasova A.G., Aksenova N.N. (2015). The Competences Model of Competitive Process Engineer. Journal of Sustainable Development, 8(3), 250 - 255. doi: 10.5539/jsd.v8n3p250

20. Laaksonen A. (2018). Competitive Programmer's Handbook. Retrieved from https://cses.fi/book/book.pdf

21. Lipowsky S.F.J. (2017). Pedagogical Means for Improvement of Self-Regulation in Self-organizing IT Group. Summary of PhD Thesis. Riga: RPIVA, 26-52. Retrieved from https://dspace.lu.lv/dspace/bitstream/handle/7/38372/sl_kopsavilkums.pdf

22. Little J. (2014). Lean Change Management: Innovative Practices For Managing Organizational Change. Happy Melly Express.

23. Mitina L.M. (2003). Psihologiya razvitiya konkurentosposobnosti lichnosti [Developmental Psychology of the Competitive Personality]. Moskva: MPSI (in Russian).

24. Pinto D., Bortolozzi F., Sartori R., Tenório N. (2017). Investigating Knowledge Management within Software Industry: A Systematic Literature Review. International Journal of Development Research 7(12), 7672-17679. Retrieved from https://www.journalijdr.com/sites/default/files/issue-pdf/11469.pdf

25. Sijin J. (2018). Programmer Competency Matrix. In Perspectives on Software, Technology and Business. Retrieved from http://sijinjoseph.com/programmer-competency-matrix/

26. Socking M. (2018). Managing Knowledge for Sustainable Future. Scientific and Technical Advisory Panel to the Global Environment Facility. Washington: STAP. Retrieved from http://stapgef.org/sites/default/files/publications/STAP\%20Report\%20on\%20KM.pdf

27. Suleimankadieva A.E., Pilipenko V.I., Sági J. (2019). Knowledge Company: Approaches to Assessing New Knowledge and Representation it to Society. Procedia Computer Science, 150, 730-736. doi: 10.1016/j.procs.2019.02.011

28. Suyazova L.V., Mustafina D.A., Rebro I.V., Rahmankulova G.A. (2013). Struktura konkurentosposobnosti budushchego inzhenera v mashinostroyenii [The Structure of Competitiveness of a Prospective Engineer in Mechanical Engineering]. European Student Scientific Journal, 2. Retrieved from http://sjes.esrae.ru/ru/article/view?id=70 (in Russian) 